\title{
INFLUENCE OF MULCHING SYSTEMS ON SOIL TEMPERATURE, PRODUCTION AND WATER USE EFFICIENCY UNDER TRICKLE IRRIGATION SYSTEM
}

\author{
A. F. Khedr*
}

\section{ABSTRACT}

The aim of this research is to study the influence of different mulching materials on soil surface temperature, water use efficiency and production. Two field experiments were conducted at the Research Farm of Faculty of Agriculture, Suez Canal University, Ismailia, Egypt, during the summer of 2016 and the winter 2017 growing season in a sandy soil under trickle irrigation system. Six treatments transparent polyethylene sheets, rice straw, maize straw and control were investigation in the field. The results showed that there were more increases in soil temperature under plastic mulch than under others treatments. The recorded soil surface temperature was lowest under rice straw mulch during both summer and winter seasons. The field investigation revealed that, the highest grain yield and water use efficiency of maize was obtained during summer which were $9563 \mathrm{~kg} \mathrm{ha}^{-1}$ and $1.54 \mathrm{~kg} \mathrm{~m}^{-3}$, respectively under rice straw mulch. During winter, faba bean gave the highest values of seed yield and water use efficiency $7521 \mathrm{~kg} \mathrm{ha}^{-1}$ and $2.20 \mathrm{~kg} \mathrm{~m}^{-3}$, respectively were achieved under transparent plastic mulch followed by rice straw mulch. Mulching method can help to improve yield of crops. It was recommended that, using $8 \mathrm{Mg} \mathrm{ha}^{-1}$ rice straw mulch in both summer and winter conditions was the best for soil temperature. It is also more attractive option by its very cheap and ease in availability and is environmental friendly.

Keywords: Trickle irrigation, Rice straw mulch, Plastic mulch, Water use efficiency, Maize and faba bean yield.

\section{INTRODUCTION}

Tmproving soil temperature management is one of the most important factors for plant growth. Although, it is common in many parts of the lowland tropics soil temperature may reach $40^{\circ} \mathrm{C}$ or more at $15 \mathrm{~cm}$ depth, relatively little information is available for root growth at supraoptimal temperature (Liu and Huang, 2005).

\footnotetext{
*Lecturer of Agric. Eng., Agric. Eng. Dep., Fac. of Agric., Suez Canal Univ., Egypt.
} 
The minimum and optimal temperatures depend upon the plant species and are typically in ranges of $0-12^{\circ} \mathrm{C}$ and $25-35^{\circ} \mathrm{C}$, respectively, while the maximum is almost around $40-45^{\circ} \mathrm{C}$ (Gregory, 2006). The optimum is often broad rather than a sharp peak and there is frequently a broad range of temperatures at which root growth rates are $\geq 50 \%$ of their maximum growth (Table 1). Both total root mass and length show similar overall responses to temperature, although the size of the response to a particular temperature may differ between the two parameters (Lynch et al., 2012).

Table (1): Soil temperature range for root growth rates $\geq 50 \%$ of maximum growth according to Klepper (1987).

\begin{tabular}{lcc}
\hline \multirow{2}{*}{ Plant } & \multicolumn{2}{c}{ Temperature } \\
& Low & High \\
\hline Flax Limum usitatissimum L. & 10 & 31 \\
Peas Pisum sativum L. & 9 & 33 \\
Common bean Phaseolus vulgaris L. & 12 & 33 \\
Maize Zea maize L. & 17 & 37 \\
Strawberry Frogaria sp & 5 & 31 \\
Broad bean Vicia faba & 12 & 32 \\
Rape Brassica napus L. & 16 & 33 \\
Oat Avena sativa L. & 9 & 32 \\
\hline
\end{tabular}

Mulches are defined as materials that are applied to, or grow upon, the soil surface, as opposed to material laid or grown over the soil surface can be considered as mulch, though some materials are more beneficial than others (Chalker-Scott, 2007). Mulch is a protective layer of either organic or inorganic material that is spread on the top soil to reduce the moisture loss from the soil by preventing evaporation from sunshine and desiccating winds, improve soil condition, prevent weed growth, provide home for earthworms and natural enemies found in the soil and reduce soil compaction from the impact of heavy rains. Mulch helps regulate soil temperature by shading it in the summer thus keeping it cooler and helps insulate it in the winter from chilling winds. This temperature regulating effect helps encourage the root growth of plants, and prevent soil erosion (Eid et al., 2013). Several investigators have reported that the soil thermal regime under mulching is different from that of bare soil, where soil temperature often being lower under mulched surface than in non- 
mulched soil (Sarkar et al., 2007). It became well known that, plastic mulch helps to maintain soil moisture for improved plant growth and development Li et al. (2011) found that plastic mulch could prevent about $93 \%$ of soil water evaporation and soil water distribution patterns were closely related to the irrigation frequency.

By limiting the underside soil evaporation, transparent plastic mulch changes the energy and water transfer between the atmosphere and the land surface. The average temperature of the upper soil layer improved by the plastic cover was approximately $3^{\circ} \mathrm{C}$ (Yang et al., 2012). Under Egyptian conditions the soil temperature of soil mulched with blue polyethylene and bare soil had a higher value than that soil mulched with transparent polyethylene and the lowest values were recorded under rice straw mulch as stated by Abd El-Kader et al. (2010). Meanwhile, transparent polyethylene gave higher soil moisture contents than that mulched with blue polyethylene, straw mulch and bare soil. Drip line is the preferred means for irrigated vegetables when using plastic mulch. The use of drip line along with plastic mulch not only allows a vegetable crop to receive adequate moisture but it is also more cost efficient than overhead irrigation (Orzolek et al., 2007). Numerous studies have concluded that soil beneath plastic mulch and irrigated with drip line will have higher moisture content than that for bare soil. The ability of plastic mulches to alter the plant microenvironment was due in part to its ability to restrict soil water evaporation (Mahbub and Zimmerman, 2006). When comparing drip irrigation to furrow irrigation Tiwari et al. (1998) established about $40 \%$ reduction in water application with the use of black plastic mulch in conjunction with drip irrigation.

Li et al. (2013) showed that both wheat straw and transparent plastic sheet mulch significantly reduced soil water loss by evaporation. However, transparent plastic sheet was more effective for conserving soil water than wheat straw mulch. Although both wheat straw and plastic sheet mulch improved soil water storage during fallow, large amounts of soil water were still lost by evaporation. The magnitude of water loss by evaporation was closely related to air temperature. Zhang $\boldsymbol{e t}$ al. (2009) used wheat straw in a rate of $0.8 \mathrm{~kg} \mathrm{~m}^{-2}$ as a surface mulch. They 
observed that, soil temperature under mulch was higher during the colder weather and lower during warmer weather compared with non-mulched soil. Meanwhile, the magnitude of the change in soil temperature due to mulching varies between studies. This variation could be attributed to the mulch application rate and/or climate conditions. Rice straw becomes a big problem to get rid of, so that the farmers oblige to burn the rice straw and this lead to environmental pollution; such straw can be used as mulch (Sadeghi et al., 2014).

Water use efficiency attained its maximum value under straw mulches, which was $45 \%$ higher than non-mulched. However, replacement of straw mulch with water hyacinth mulch narrowed the difference to $37 \%$ Sarkar et al. (2007).

The study objectives was investigating the effect of soil surface mulching systems on soil temperature, and its effect on productivity of maize in the summer season and faba bean in the winter season and on water use efficiency under trickle irrigation system too.

\section{MATERIALS AND METHODS}

\section{Experimental layout}

The experiments were carried out in sandy soil, at the Experimental Research Farm of Faculty of Agriculture, Suez Canal University, Ismailia, Egypt (the coordinate for this location is $30^{\circ} 58^{\prime} \mathrm{N}$ and $32^{\circ} 23^{\prime} \mathrm{E}$, and $13 \mathrm{~m}$ elevation above sea level), Egypt, during two seasons, summer 2016 and winter 2017. The experimental design was complete randomized block design in three replicates. Irrigation system components consisted of water source from Ismailia canal, control head, pumping, filtration unit, pressure regulator, pressure gauges, flow meter, and control valves. Main line was PVC pipes with $110 \mathrm{~mm}$ in diameter to convey the water from the source to the main control points in the field. Submain lines were $P V C$ pipes with $75 \mathrm{~mm}$ diameter was connected to the main line. Manifold lines: $P E$ pipes were $63 \mathrm{~mm}$ in diameter was connected to the submain line. Emitters, built in laterals line of polyethylene $(P E)$ with $16 \mathrm{~mm}$ diameter were connected with manifold line and $40 \mathrm{~m}$ in long (emitter discharge was $4 \mathrm{\ell} / \mathrm{h}$ at $0.1 \mathrm{MPa}$ operating 
pressure) and $30 \mathrm{~cm}$ spacing between emitters. The coefficient of uniformity $(C U)$ of the irrigation network was determined and its value was $98.85 \%$ under the prescribed working pressure (Khder, 2015).

The six treatments were investigation in the field. The $1^{\text {st }}$ treatment was transparent polyethylene sheets (TPS), were cut in a strips of $40.5 \mathrm{~m}$ long and $0.75 \mathrm{~m}$ width. The sheets were laid down on the soil surface over the lateral line. Holes of $0.05 \mathrm{~m}$ in diameter were made over each emitter in the center of the strip for planting. The TPS treatment was conducted only during the winter season and excluded from the treatments during the summer season. The $2^{\text {nd }}$ treatment was the application of $8 \mathrm{Mg} \mathrm{ha}^{-1}$ of the prepared rice straw as surface mulch $\left(R S_{8}\right)$, on which fishing net was used to stabilize it. The $3^{\text {rd }}$ treatment involved the use of $12 \mathrm{Mg} \mathrm{ha}^{-1}$ of the rice straw as surface mulch $\left(R S_{12}\right)$, where the method of application was similar to the $2^{\text {nd }}$ treatment. The $4^{\text {th }}\left(M S_{8}\right)$ and $5^{\text {th }}\left(M S_{12}\right)$ maize straw treatments were application at the same treatments $2^{\text {nd }}$ and $3^{\text {rd }}$. The last treatment was a control $(C)$. Rice and maize straw samples were obtained, air dried and cut to $5-8 \mathrm{~cm}$ and $8-12 \mathrm{~cm}$, respectively pieces for using as straw mulch. A transparent poly ethylene sheets $1.20 \mathrm{~mm}$ thickness also used as mulch. This kind of polyethylene sheets are usually used in agricultural practices by local farmers.

Maize grains (Zea mays L. var TWC 352) were planted on $1^{\text {st }}$ May and harvested on $2^{\text {nd }}$ September 2016, so the growing season was lasted to 125 days in the summer season, while faba bean seed (Vicia faba L. var Giza 843) was planted in $30^{\text {th }}$ November 2016 to $28^{\text {th }}$ April 2017 (after 150 days) as winter crop, estimation of seed yield and its components characters were made at harvest. Two seeds were placed in holes $0.30 \mathrm{~m}$ apart on rows, $40.0 \mathrm{~m}$ long and $0.70 \mathrm{~m}$ between rows. After two weeks, the seedlings were thinned to one each hole. Normal agricultural practices were made to prepare the soil for cultivation and plant fertilization as described by the Egyptian Ministry of Agriculture for the two crops. Weeds, pest and diseases control were done in timely manner. The population density for plants was 47619 plants ha $^{-1}$. The amount of irrigation water needed in $\mathrm{mm} / \mathrm{season}$ was calculated according to the daily reference evapotranspiration $\left(E T_{o}, \mathrm{~mm} /\right.$ day $)$ and the crop coefficient 
$\left(K_{c}\right)$. The values of $E T_{o}$ were using CROPWAT software version 8.0 based on Penman-Monteith equation (Allen et al., 2011).

Soil analyses are shown in Table (2), soil mechanical analysis was carried out using the international pipette method. The dry bulk density $(D B D)$ of soil was determined using undisturbed soil cores according to Klute (1986). The analysis showed that at this depth the soil is considered to be homogeneous layer. The water content at field capacity $(F C)$, was measured by the method described by Tan (2005). Available water $(A W)$ was calculated based on Allen et al. (2011).

Table (2): Physical characteristics of the experimental soil.

\begin{tabular}{ccccccccc}
\hline $\begin{array}{c}\text { Soil } \\
\text { depth }\end{array}$ & \multicolumn{2}{c}{ Particle size } & distribution $\%$ & Texture & DBD & FC & PWP & $A W$ \\
$(\mathrm{~cm})$ & Sand & Silt & Clay & Class & $\left(\mathrm{g} / \mathrm{cm}^{3}\right)$ & $(\%)$ & $\begin{array}{c}\text { (\%) } \\
(\%)\end{array}$ \\
\hline $0-20$ & 95.24 & 1.80 & 2.96 & Sand & 1.631 & 8.6 & 1.8 & 6.8 \\
$20-40$ & 95.67 & 1.76 & 2.57 & Sand & 1.670 & 8.6 & 1.8 & 6.8 \\
\hline
\end{tabular}

FC: Field capacity (- 0.1 atm), PWP: Permanent wilting point (- $15 \mathrm{~atm})$.

Soil temperatures were measured under all treatments at $15 \mathrm{~cm}$ soil depth every hour from sunrise to sunset. Digital soil thermometer $\left( \pm 0.1^{\circ} \mathrm{C}\right)$ was used for such measurements.

The water application time was calculated as in the following equation (Merriam and Keller, 1978):

$$
I_{t}=\frac{I W R}{q_{i}}
$$

Where, $I_{t}$ is water application time (h), IWR is amounts of applied irrigation water ( $\ell /$ Irri.), and $q_{i}$ is the emitter discharge $(\ell / h)$.

The total weight of the crop in each treatment was use to determine the water use efficiency (WUE), the WUE was calculated according to Abd El-Kader et al. (2010).

$$
F W U E=\frac{Y_{i}}{W_{a}}
$$

Where, FWUE is field water use efficience $\left(\mathrm{kg} / \mathrm{m}^{3}\right), Y_{i}$ is total weight of grain yield $(\mathrm{kg} / \mathrm{fed})$ and $W_{a}$ is total water applied $\left(\mathrm{m}^{3} / \mathrm{fed}\right)$. 
Statistical analysis, for the field experiments, the obtained data were subjected to analysis of variance (ANOVA) using Costat Statistical Software, version 6.311 (Cohort Program, 1990). The least significant difference test $(L S D)$ was applied to make comparison between the means $(\mathrm{P}<0.05)$.

\section{RESULTS AND DISCUSSION}

Influence of soil surface mulching application on plant growth and yield of maize

The experiment involved five treatments, namely: $R S_{8}, R S_{12}, M S_{8}, M S_{12}$ and $C$. The reason for excluding TPS mulch during the summer was that, the root temperature ranges for root growth rates $\geq 50 \%$ of maximum for maize plant was $17-37^{\circ} \mathrm{C}$ as listed by Klepper (1987). The recorded soil temperature under plastic mulch during the summer for the primary experiment was higher than $37^{\circ} \mathrm{C}$ for more than 5 hours daily. Such high temperature was expected to affect negatively the root growth, development and function. So, it was expected to have a feeble plant with less production ability under TPS treatment. The trickle irrigation method was used to irrigate the plants and the total amount of irrigation water used during the growing season was $622.22 \mathrm{~mm} / \mathrm{season}$.

\section{Soil temperature and moisture for summer 2016 (Maize)}

At the middle of the growing season (on $2^{\text {nd }}$ July 2016) soil temperature were measured under all treatments at $15 \mathrm{~cm}$ soil depth every hour from sunrise to sunset. Air temperature at the height of the plant canopy was also measured every hour, and the obtained results are shown in Figure (1). The data showed that, the maximum soil temperatures reported were 33.1, 33.6, 34.8, 35.6 and $36.8^{\circ} \mathrm{C}$ for $R S_{8}, R S_{12}, M S_{8}, M S_{12}$ and $C$ treatments, respectively. On the other hand, the minimum soil temperatures were $26.7,25.9,24.6,25.6$ and $25.4^{\circ} \mathrm{C}$ for investigated treatments, respectively. So, the average obtained for the soil temperatures were $6.4,7.7,10.2,10.0$ and $11.4^{\circ} \mathrm{C}$ for the investigated treatments, respectively. It is obvious that, the highest average of soil temperature was obtained under $M S_{8}, M S_{12}$ and $C$ treatments, while the lowest value was obtained under $R S_{8}$ treatment. The air temperatures for that day were 42.5 and $20.1^{\circ} \mathrm{C}$ for maximum and minimum values, respectively, with average of $22.4^{\circ} \mathrm{C}$ according to Klepper (1987), the 
root temperature ranges for root growth rates $\geq 50 \%$ of maximum for maize plant was $17-37^{\circ} \mathrm{C}$. Under $C, M S_{8}$ and $M S_{12}$ treatments, soil temperature was close to $37^{\circ} \mathrm{C}$ during the middle. Such high temperature was expected to negatively affect the root growth, development and function. So, it is expected to have less production under such treatments. On the other hand, the temperature values recorded under $R S_{8}$ may lead to high plant growth with high yield.

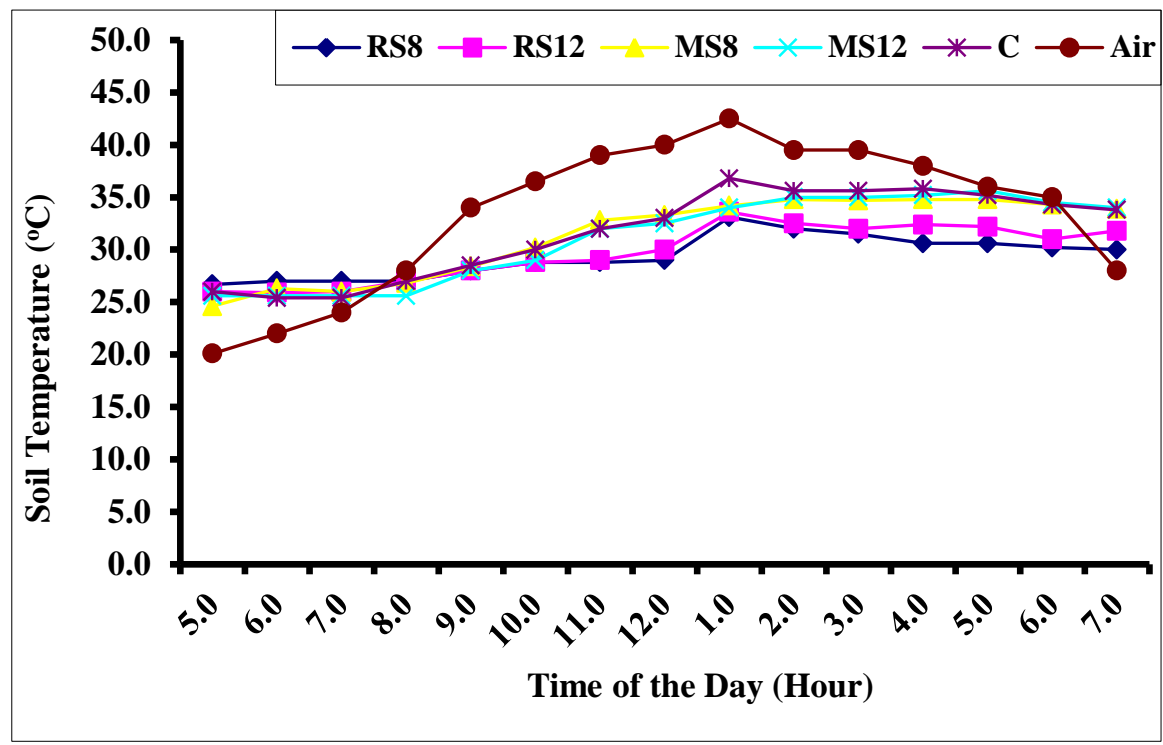

Figure (1). Soil temperature measured under different treatments for maize plants, measured from sunrise to sunset during summer.

It is important to detect the effect of soil moisture on its temperature changes for the different treatments under the same climatic conditions and irrigation water amount. Soil temperature was measured directly at $8.30 \mathrm{am}$ before irrigation and $5.00 \mathrm{pm}$ on the next day of irrigation. Such measurements were conducted two times weekly. Figure (2) shows the monthly average soil temperatures. The results clearly showed that, the values of soil temperatures measured at 8.30 am were lower than that measured at $5.00 \mathrm{pm}$ on the next day of irrigation. In both measurement times, the highest soil temperature was found under $C$ treatments during the four months of the growing season, while the lowest was found under $R S_{8}$ treatment. The highest soil temperature recorded was $33.95^{\circ} \mathrm{C}$ for $C$ treatment before irrigation on August, while the lowest recorded value 
was $28.11^{\circ} \mathrm{C}$ for $R S_{8}$ during May, 2016. For soil temperature data recorded next day of irrigation, the highest value was $35.83^{\circ} \mathrm{C}$ for $C$ treatment during June, while the lowest value was $30.11^{\circ} \mathrm{C}$ for $R S_{8}$ treatment during May, 2016. The differences between $M S_{8}$ and $M S_{12}$ treatments were very small. However, $C$ treatment recorded higher soil temperature for all treatment.

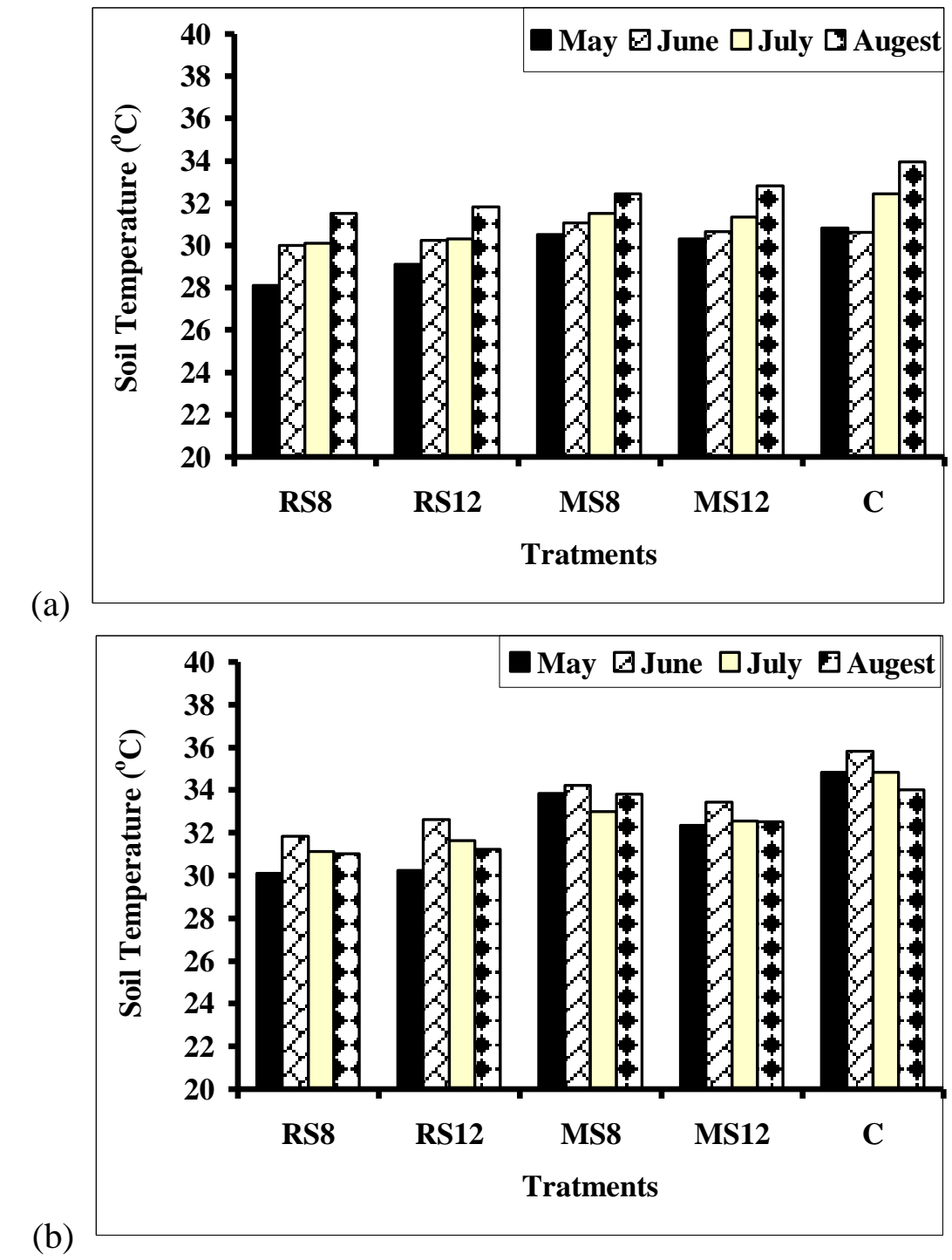

Figure (2). Soil temperature measured in the root zone of maize plants during summer (a) before irrigation and (b) after irrigation. 
Figure (3) shows the volumetric soil moisture content measured before and after irrigation. All the investigated treatments enhanced soil moisture storage compared to control. The most efficient practice was $R S_{8}$ treatment which gave the higher soil moisture content before irrigation, $0.027 \mathrm{~cm}^{3} \mathrm{~cm}^{-3}$, compared to $C$ that recorded $0.017 \mathrm{~cm}^{3} \mathrm{~cm}^{-3}$. After irrigation, the treatments $M S_{8}, M S_{12}$ and $\mathrm{C}$ were nearly similar in their moisture contents. The values reached $0.103,0.105$ and $0.102 \mathrm{~cm}^{3} \mathrm{~cm}^{-3}$, respectively. On the other hand, the treatments $R S_{8}$ and $R S_{12}$ recorded much more soil moisture contents; their values were 0.141 and $0.121 \mathrm{~cm}^{3}$ $\mathrm{cm}^{-3}$, respectively. Such relatively high values could be attributed to that, an artificial barrier with straw mulch helped for slow and steady entry of water and thus reduced drainage loss (Moitra et al., 1996).

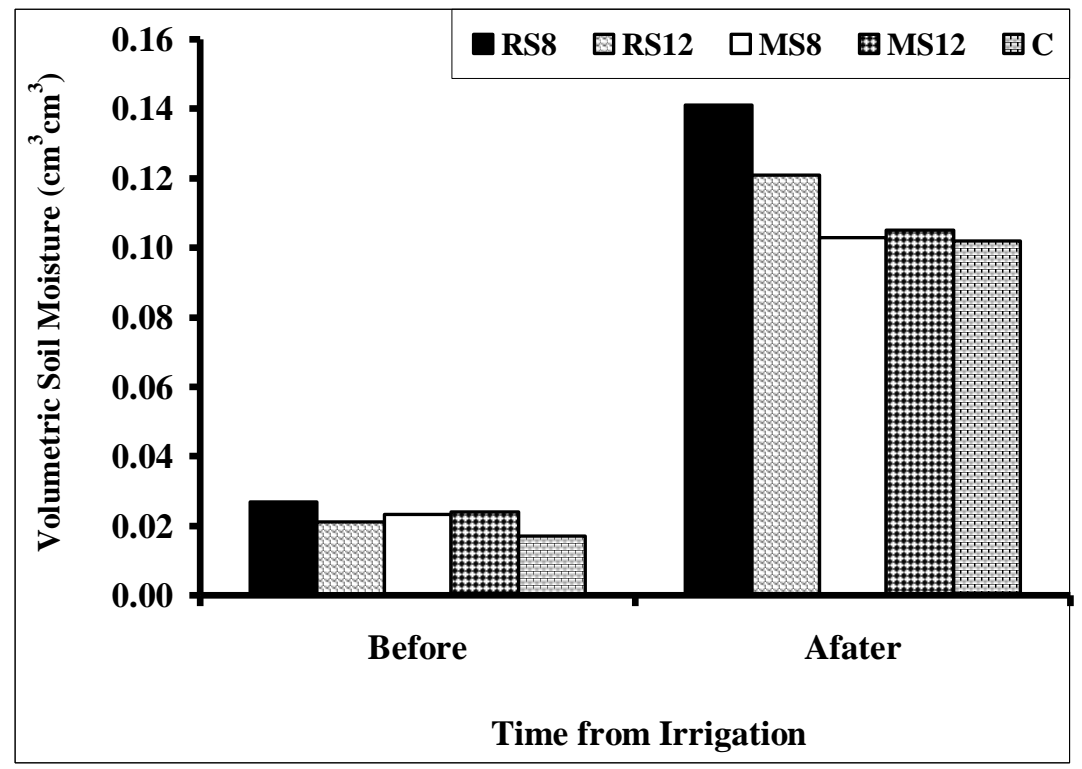

Figure (3). Volumetric soil moisture contents in the root zone of maize plants before and after irrigation during the middle season.

\section{Maize yield and water use efficiency}

At the end of the growing season, 10 plants from each replicate were taken to determine yield and water use efficiency (WUE). The data were presented in Figures (4 and 5). For all the investigated parameters, $C$ treatment recorded the lowest values. However, $R S_{8}$ treatment recorded the highest values, and they were significantly difference from all other treatments. 


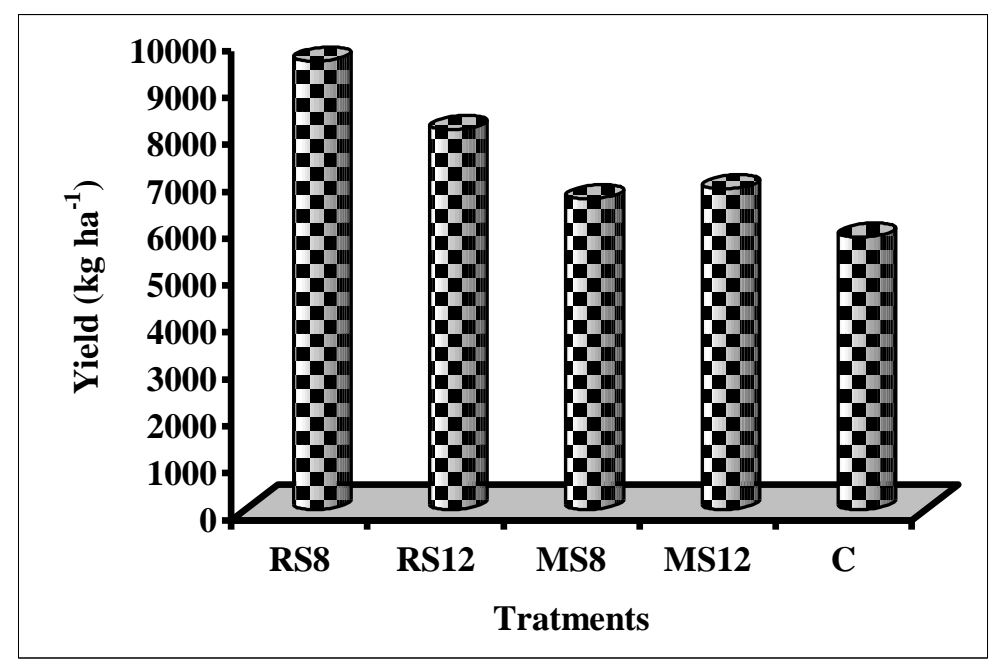

Figure (4): Yield of maize plants under different treatments.

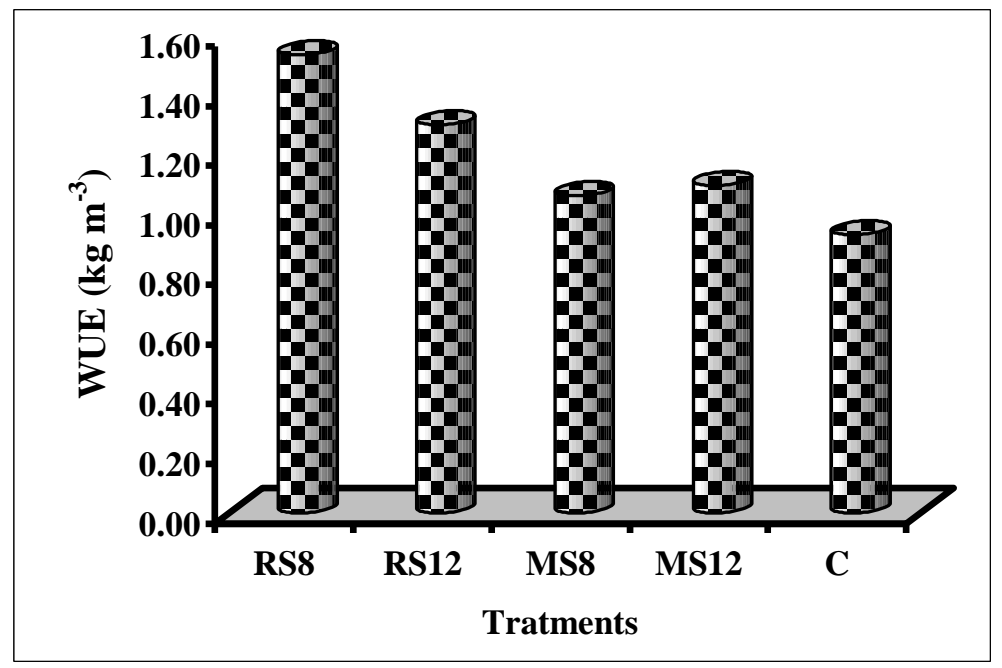

Figure (5). Water use efficiency (WUE) of maize plants under different treatments.

In regard to the grain yield in $\mathrm{kg} \mathrm{ha}^{-1}$, all the investigated treatments gave higher yield than the control $C$ treatment, the percentage yield increases were $64.81,39.54,14.13$ and $17.75 \%$ for $R S_{8}, R S_{12}, M S_{8}$ and $M S_{12}$, respectively. While, the highest value of $W U E 1.54 \mathrm{~kg} \mathrm{~m}^{-3}$ was achieved at $R S_{8}$ treatment, which could be recommended for trickle irrigated maize in sandy soil. When considering the effects of the current treatments on soil moisture and temperature, straw mulching found to conserve soil moisture by reducing the amount of losses evaporation. This means more 
availability of water to plants. In general, mulch management and straw mulch particularly, helped in conservation of soil moisture in the root zone, which ultimately influenced grain yield. In the other words, high moisture content increased root proliferation and thus enhanced availability of nutrients to crop roots. This finding is in agreement with (Sharma et al., 1997; Sarkar and Rana, 1999' Sarkar, 2005).

Influence of soil surface mulching application on growth and yield of faba bean

The current investigation involved the same experimental setup and treatments conducted for maize plants during summer 2016, in addition to transparent plastic mulch treatment. Therefore, the investigated treatments were: $T P S, R S_{8}, R S_{12}, M S_{8}, M S_{12}$ and $C$. Trickle irrigation was used to irrigate plants and the total amount of irrigation water used during the growing season was $341.52 \mathrm{~mm} / \mathrm{season}$.

\section{Soil temperature and moisture for winter 2017 (Faba Bean)}

At the middle of the growing season, (on 12 $2^{\text {th }}$ February 2017) soil temperatures were measured under the various treatments, in the field soil at $15 \mathrm{~cm}$ soil depth. Air temperatures at the highest of plants canopy were also measured. The measurements time extended from sunrise to sunset, and the obtained data were shown in Figure (6).

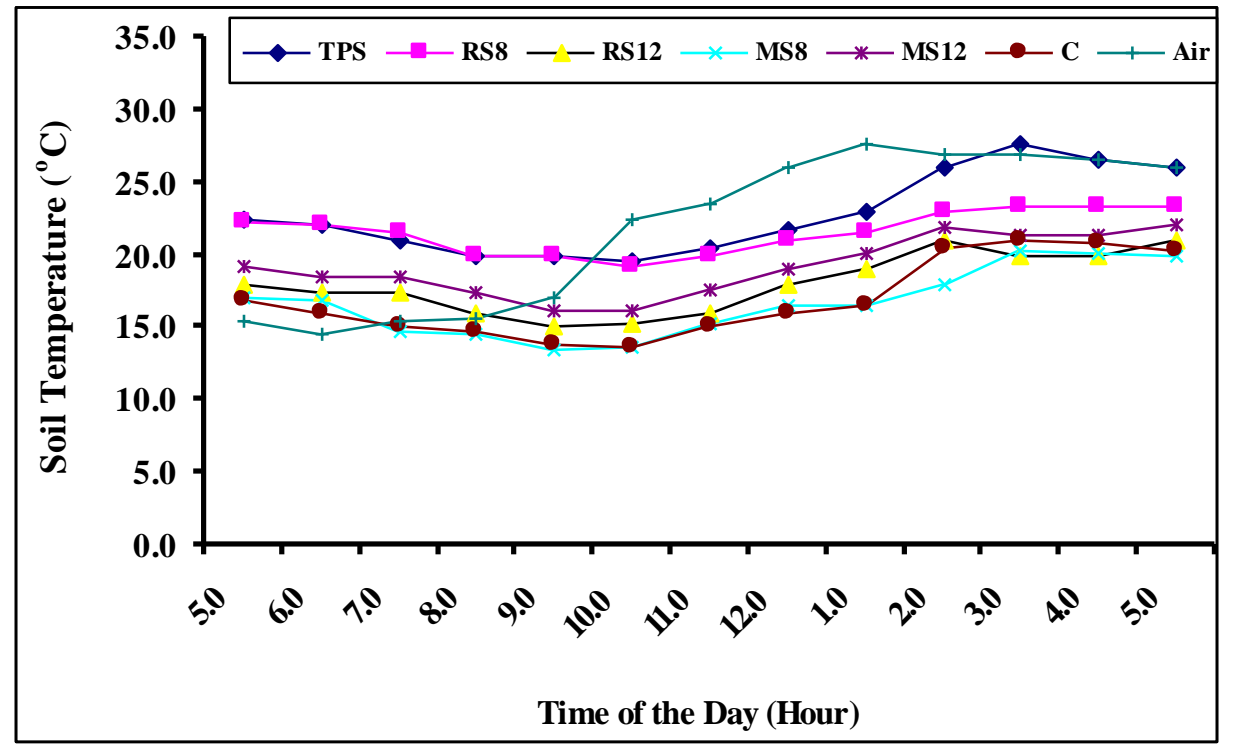

Figure (6). Soil temperature measured under different treatments for bean plants, measured from sunrise to sunset during winter. 
The results showed that, the average soil temperatures obtained were 8.0, 4.2, 6.0, 6.8, 5.8 and $7.4^{\circ} \mathrm{C} T P S, R S_{8}, R S_{12}, M S_{4}, M S_{12}$ and $C$ treatments, respectively. these results with obtained the highest average of soil temperature was found under TPS treatment and the lowest was found under $R S_{8}$ treatment.

The soil temperature was measured directly before and on the next day of irrigation. Figure (7) shows the monthly average data of soil temperature.

(a)
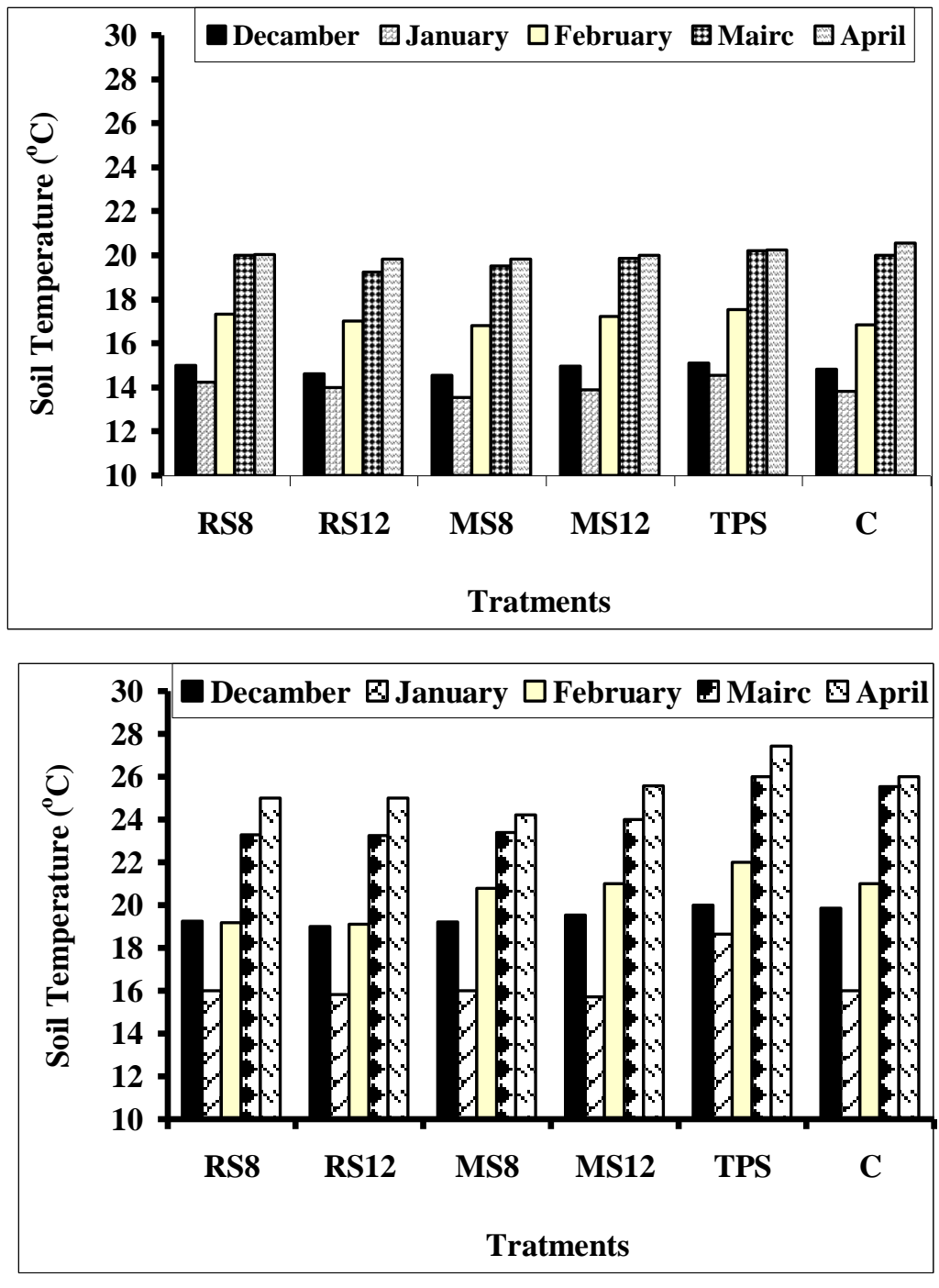

Figure (7). Soil temperature measured in the root zone of bean plants during winter (a) before irrigation and (b) after irrigation. 
Data indicated that, the lowest soil temperature in both, before and after irrigation were recorded in January, 2017. Then the soil temperature started to rise gradually in the following months. For both measurement times, TPS treatment recorded the highest soil temperature. In several cases, the differences between $R S_{8}, R S_{12}, M S_{8}$ and $M S_{12}$ were very small.

The volumetric soil moisture contents before and after irrigation were shown in Figure (8). The plastic mulch resulted in more soil moisture content before irrigation compared with the other investigated treatments. While $R S_{8}$ and $R S_{12}$ were nearly equaled to each other, but still more than the control $C$. The situation after irrigation was changed dramatically, where TPS recorded the lowest soil moisture content followed by the control. The $R S_{12}$ treatment recorded the highest soil moisture contents after irrigation. Its value equaled $0.176 \mathrm{~cm}^{3} \mathrm{~cm}^{-3}$, and was more than soil field capacity. That is because the samples were taken after irrigation.

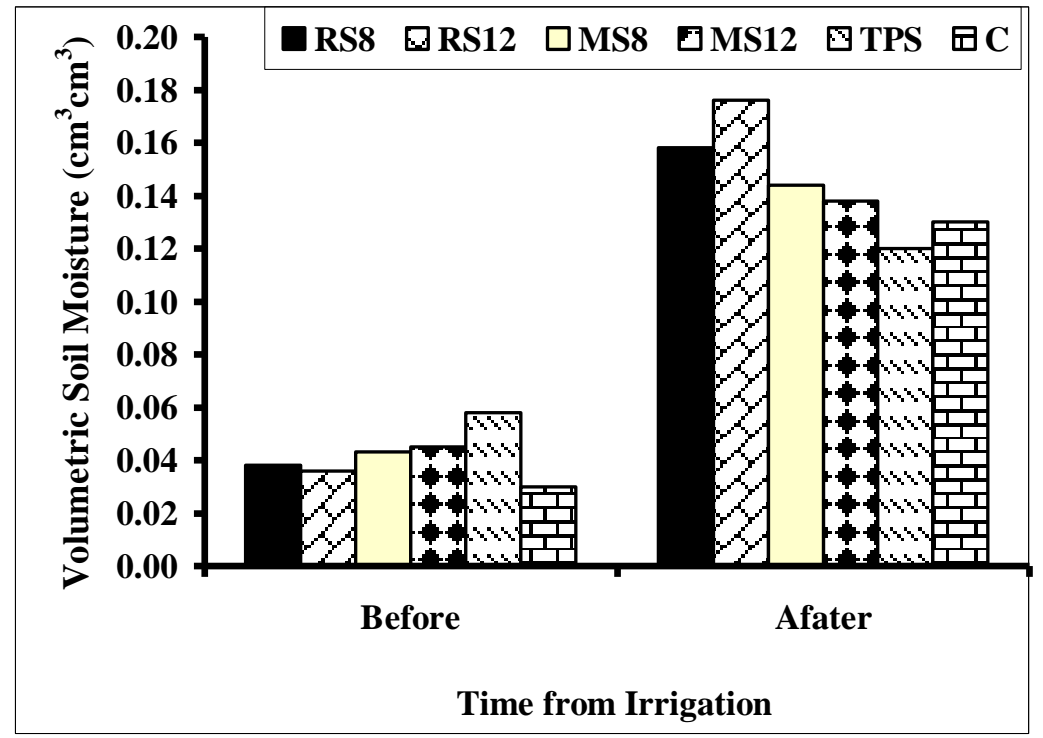

Figure (8). Volumetric soil moisture contents in the root zone of bean plants before and after irrigation during the middle of the growing.

\section{Bean yield and water use efficiency}

The obtained results for the investigated that, TPS treatment recorded the highest values for all investigated parameters, and were significantly difference from all other treatments and followed by $R S_{8}$ treatment, and still significantly higher than the $C$ control as shown in Figures ( 9 and 
10). The $R S_{12}$ treatment came in middle position between $R S_{8}$ and $M S_{8}$, $M S_{12}$ treatments. The seed yield percent of increase compared to control were $230.77,190.53,123.55,74.14$ and $84.30 \%$ for $T P S, R S_{8}, R S_{12}, M S_{8}$, and $M S_{12}$ treatments, respectively.

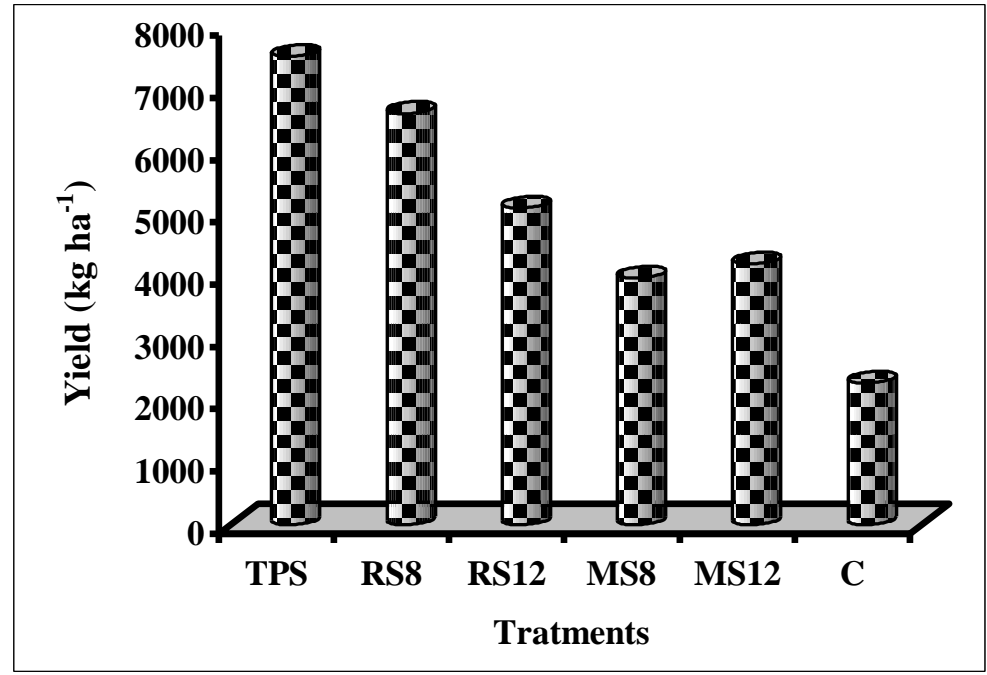

Figure (9): Yield of bean plants under different treatments.

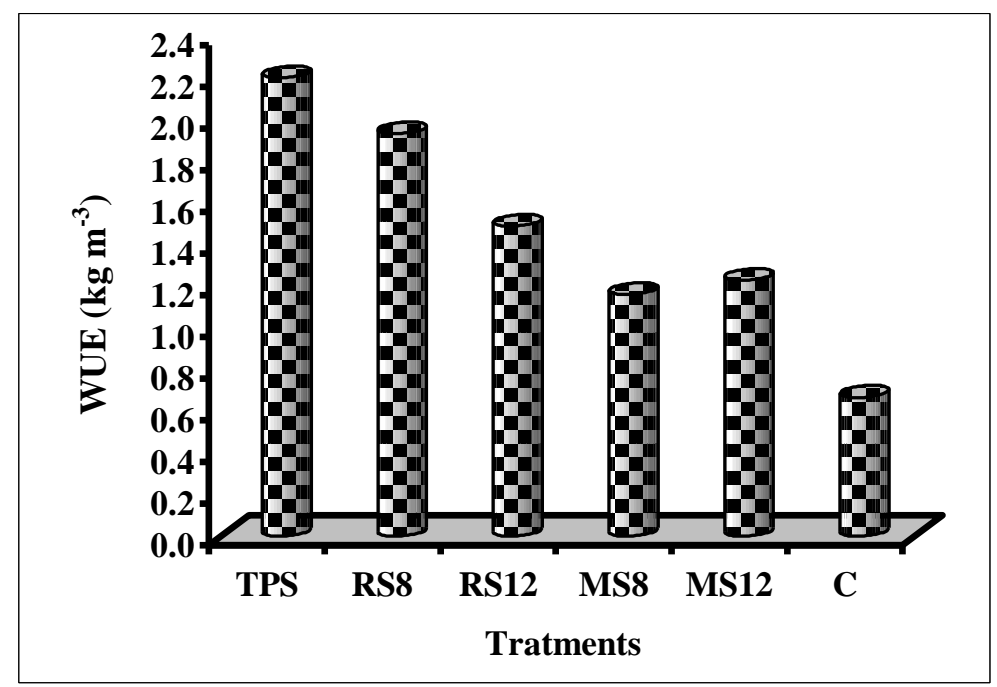

Figure (10). Water use efficiency (WUE) of bean plants under different treatments.

Such high values which exceeds the double in TPS treatment could be attributed to that, this high temperature (i.e., $27.6^{\circ} \mathrm{C}$ ) was almost in the middle position between the values of $12-32^{\circ} \mathrm{C}$ reported by Klepper 
(1987) for root growth of bean. Also, the highest value of WUE $2.20 \mathrm{~kg}$ $\mathrm{m}^{-3}$ was achieved at TPS treatment. In other words, the response of bean to the investigated treatments was mulch higher than that found for maize crop. These findings could be attributed to botanical and physiological differences between the two crop plants.

From the previous discussion, it could be concluded that, TPS treatment was the most efficient treatment to ameliorate soil moisture and temperature under bean plants during winter 2017. Rice straw mulch also reported a significant increase in crop yield and growth parameters. The $M S_{8}$ and $M S_{12}$ were significantly produced high yield compared to control, but still less than that found under both TPS and $R S_{8}$ treatments. So, the choice was exclusive between plastic mulch and rice straw mulch. With considering the environmental friendship of straw mulch and its effect on increasing soil organic matter, the most attractive choice could be provided using the straw mulch.

It was detected that, the highest crop yield obtained under summer conditions was responded to minimizing soil temperature. On the other hand, the highest crop yield obtained under winter conditions was responded to the relative increasing in soil temperature. The current study recommended the use of rice straw as soil mulch in both summer and winter seasons. It provides an attractive option by its low cost and ease in availability and application. It is also better in the long run as it improves soil organic matter and is environmental friendly. It also has the ability to moderate the soil temperature during the summer and winter conditions. By reducing evaporation much available moisture for plants will be provided.

\section{CONCLUSION}

The obtained results can be summarized as following:

1- Under both summer and winter conditions, soil temperature was lower under high moisture levels and increased with the decreased in soil moisture contents.

2- Under both summer and winter conditions, both transparent plastic mulch $(T P S)$ and $8 \mathrm{Mg} \mathrm{ha}^{-1}$ rice straw mulch $\left(R S_{8}\right)$ greatly reduced the rate of water evaporation from the soil compared to other treatments. 
3- Soil temperature measured under field conditions during the summer revealed that, $R S_{8}$ gave the lowest soil temperature compared to other treatments.

4- During the winter season field soil temperature showed that, the TPS gave the highest soil temperature, while $R S_{8}$ gave the lowest soil temperature.

5- The highest yield and water use efficiency (WUE) of maize was obtained by using $R S_{8}$, while the highest yield and WUE of bean was obtained by using TPS.

\section{REFERENCES}

Abd El-Kader, N.; A. Derbala and M. E. M. Ahmed (2010). Influence of mulching and some micro-nutrients usage on soil temperature, soil moisture, growth and cowpea yield. Research Journal of Agriculture and Biological Sciences, 6(4): 505 - 513.

Allen, R. G.; L. S. Pereira; R. Dirk and M. Smith (2011). Crop Evapotranspiration Guidelines for Computing Crop Water Requirements. FAO Irrigation and Drainage Paper No. 56, 1998. Food and Agriculture Organization. Rome, Italy, pp. 83.

Chalker-Scott, L. (2007). Impact of mulches on landscape plants and the environment- A Review. J. Environ. Hort. 25(4): 239 - 249.

Cohort Program (1990). CoStat Statistical Software. CoStat Manual Revision 4.2. pp:271.

Eid, A. R.; B. A. Bakry and M. H. Taha (2013). Effect of pulse drip irrigation and mulching systems on yield, quality traits and irrigation water use efficiency of soybean under sandy soil conditions. Agricultural Sciences. 4(5): 249 - 261.

Gregory, P. J. (2006). Plant Roots: Growth, Activity and Interaction with Soils. Blackwell Publishing Ltd, Oxford, UP. pp 132.

Khedr, A. F. (2015). Development of an engineering model for microirrigation system in maize fields. Unpublished Ph.D. Thesis of Agric. Eng., Agric. Eng. Dept., Fac. Agric., Suez Canal Univ., Egypt, 148 pp. 
Klepper, B. (1987). Root growth and temperature. Root Develop. Funct. $103,200-205$.

Klute, A. (1986). Methods of soil analysis. Part 1. Physical and mineralogical methods ( $2^{\text {nd }}$ edition). American Society of Agronomy Inc., Madison, Wisconsin, USA.

Li, S. X.; Wanga, Z. H.; Li, S. Q.; Gaoa, Y. J. Tiana, X. H. (2013). Effect of plastic sheet mulch, wheat straw mulch and maize growth on water loss by evaporation in dryland areas of China. Agricultural Water Management. 116: 39 - 49.

Li, Z. G.; Zhang, R. H.; Wang, X. J.; Wang, J. P.; Zhang, C. P. and Tian, C. Y. (2011). Carbon dioxide fluxes and concentrations in a cotton field in northwesterm China: Effects of plastic mulching and drip irrigation. Pedosphere. 21(2): 178 - 185.

Liu, X. and Huang, B. (2005). Root physiological factors involved in cool-season grass response to high soil temperature. Environ. Exp. Bot. 53, 233 - 245.

Lynch, J.; Maschner, P. and Rangel, Z. (2012). Effect of Internal and external factors on root growth and development. Chapter 13.331446 pp. in Marschner, P. (Editor) (2012). Marschner's Mineral Nutrition of Higher Plants. $3^{\text {rd }}$ ed. Academic Press in an imprint of El-Sevier, New Yourk.

Mahbub, A. and Zimmerman, R. (2006). Kansas State University Research and Extension. 20 March 2006. on Line at http//www.oznet.ksu.edu/swao/Irrigation/Kabocha\%20Study\%20re port\%20Latest.pdf.

Merriam, J. L. and J. Keller (1978). Farm Irrigation System Evaluation: A Guide for Management $3^{\text {rd }}$ ed. Logan, Utah: Agricultural and Irrigation Engineering Department, Utah State University, pp. 271.

Moitra, R.; D. Ghosh and S. Sarkar (1996). Water use pattern and productivity of rainfed yellow sarson (Brassica ropa L.var glauca) in relation to tillage and mulching. Soil Till. Res. 38, 153 - 160.

Orzolek, M. D.; J. Murphy and J. Ciardi (2007). The effect of colored polyethylene mulch on yield of squash, tomato and cauliflower. 
Penn State Center for Plasticulture. 31 January 2006. http://plasticulture.cas.psu.edu/cmulch-93.htm.

Sarkar, S. (2005). Evapotranspiration and yield response of wheat to irrigation frequencies and fertilizer levels. J. Indian Soc. Soil Sci. $53,54-59$.

Sarkar, S. and S. K. Rana (1999). Role of tillage on productivity and water use pattern of rice-wheat cropping system. J. Indian Soc. Soil Sci. 47, 532 - 534.

Sarkar, S.; M. Paramanick and S. B. Goswami (2007). Soil temperature, water use and yield of yellow sarson (Brassica napus L. Var. glauca) in relation to tillage intensity and mulch management under rainfed lowland ecosystem in eastern India. Soil Till. Res. 93, 94 - 101.

Sadeghi, S. H. R.; L. Gholami1; E. Sharifi and A. Khaledi (2014). Scale effect on runoff and soil loss control using rice straw mulch under laboratory conditions. Solid Earth Discuss., 6:2915 - 2938.

Sharma, P. K.; T. S. Verma and L. Bhushan (1997). Effect of depth of root-zone on growth, yield and nutrient uptake of rice. Oryza 34, $234-237$.

Tan, K. H. (2005). Soil Sampling, Preparation and Analysis. Taylor \& Francis Group. London.

Tiwari, K. N.; P. K. Mal; R. W. Singh and A. Chattopadhyay (1998). Response of okra (Abelmoschus esculentus L. Moench.). Agr. Water Management, 38: 91 - 102.

Yang, Q.; H. Zuo; X .Xiao; S. Wang; B. Chen and J. Chen (2012). Modeling the effects of plastic mulch on water, heat and $\mathrm{CO}_{2}$ fluxes over cropland in an arid region. Journal of Hydrology, 452453(2012) 102 - 118.

Zhang, S.; L. Lovdahl; H. Grip; Y. Tong; X. Yang and Q. Wange (2009). Effects of mulching and catch cropping on soil temperature, soil moisture and wheat yield on the loess plateau of China. Soil Till. Res. 102, 78 - 86. 


\section{الملخص العربى}

\section{تأثثير نظم التغطية على درجة حرارة التربة، إنتاجية وكفاءة إستخدام المياه تحت نظام الري بالتتقيط \\ أحمد فتحى محمد خضر}

الهدف من هذه الدراسة هو دراسة تأثير تغطية سطح التربة ببعض المعاملات المختلفة مثل التغطية بقش الأرز و الذرة و البلاستيك الثفاف على النظام الحرارى لأر اضى الإنى الإسماعيلية خشنة القو ام وكذلك إنتاجية المحصول وكفاءة استخدام المياه، لتحقيق هذه الأهداف تم إجر اء تجربتين حقليتين في مزرعة البحوث بكلية الزراعة جامعة قناة السويس - الإسماعيلية خلال صيف الإه

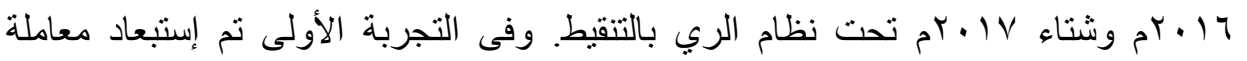
التغطية بالبلاستيك الثفاف خلال موسم الصيف وذلك لعدم ملائمتها لنمو نبات الذرة الثامية. أظهرت النتائج المتحصل عليها أن إستخدام البلاستلك الثفاف كغطاء للتربة إلى زيادة التباين الحرارى اليومى خلال فصل الشتاء، و أدى إستخدام فش الأرز كغطاء سطحى بمعدل $\wedge$ طن

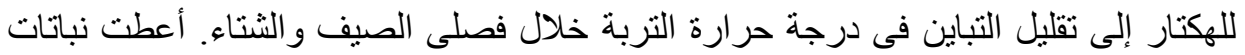

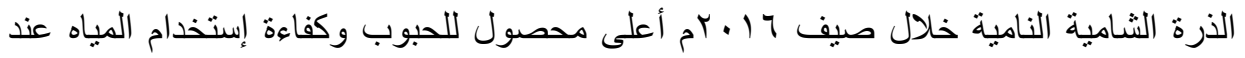

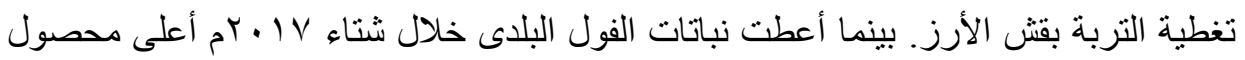
للبذور وكفاءة إستخدام المياه عند إستخدام البلاستيك الثفاف كغطاء لسطح التربة وكانت نتائج قش الأرز قريبة من ذلك. وبناءً على ذللك توصى الدراسة بإستخدام فش الأرز كغطاء سطحى

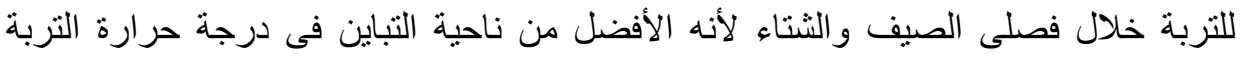
وكذلك لإنخفاض تكلفة إضافته وتوفره وسهولة إضافته لسطح التربة وكونه مادة طبيعية غير

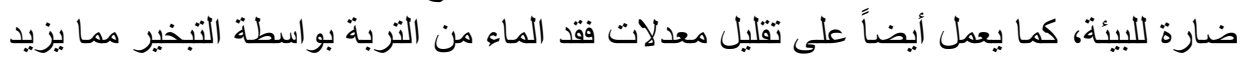

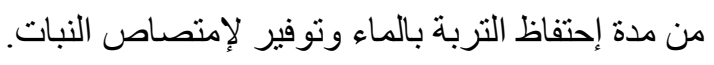

